\title{
THE REgulatory TREATMENT OF LIQUIDITY RISK IN SOUTH AFRICA ${ }^{1}$
}

\author{
Johann Jacobs and Paul Styger \\ School of Economics, North-West University
}

Gary van Vuuren

Fitch Ratings, London and School of Economics, North-West University

Accepted: January 2012

\begin{abstract}
The Basel accord describes the regulatory capital requirements for credit, market and operational risk. The accord aims to provide guidelines to level the playing field for all internationally active banks and to protect consumers against these risks. Despite the growing significance to bank solvency of liquidity risk, it is omitted from the new accord ${ }^{2}$. Banks are not required to measure and manage this risk yet they are often considerably exposed to the threat of severely diminished liquidity. This omission from the accord could have dire consequences for banks and the economy in which they operate: liquidity crises can occur without warning and spread quickly to other parts of the financial system. This article critically explores current practices in South Africa and proposes guidelines for effective liquidity risk regulation.
\end{abstract}

Key words: liquidity risk, Basel II, regulatory capital, South Africa

JEL: G28

\section{1}

\section{Introduction}

Central to bank liquidity is the fact that most banks are in the business of liquidity transformation, i.e. they take deposits that are often payable to customers on demand or on notice over a short period and use it to fund credit facilities to borrowers over longer periods (Financial Supervision Commission, $2005: 2)$. It is often argued that credit risk is the single largest risk facing banks, but more banks have failed because of liquidity risk than credit risk (Hoggarth, Reidhill \& Sinclair, 2003:109). Banks are particularly vulnerable to sudden unexpected demands for funds.

Liquidity problems experienced by a particular bank can quickly and easily spread to other banks and cause systemic risk (Reserve Bank of Australia, 1998:1), thereby causing contagion effects across an entire banking system. West (2004:8-13) identified some major financial risk management crises that occurred during the past decade and found liquidity risk to be central. High-profile financial disasters such as those by Orange County Municipality, Barings Bank, Long Term Capital Management (LTCM), Enron and Amaranth Advisors LLC have reiterated the integral part that risk management has to play in the day-to-day management of banks and other institutions. It is, therefore, important that liquidity risk management be part of banks' overall risk management strategies. Tighter regulation (in the form of higher capital requirements) and an obligation to obtain long-term subordinated debt or specific liquid asset reserve requirements are two possible solutions (Wolf, 2007).

The Core Principles for Effective Banking Supervision, developed by the Bank for International Settlements (BIS) in co-operation with fellow regulators, have effectively become the standard for sound prudential regulation and supervision of banks (BIS, 2006a:1). The Basel Core Principles were first introduced in 1997 and revised in 2006. These determine the fundamental factors for banking supervision and represent the measures used for assessing 
the performance of the Bank Supervision Department (BSD) of the South African Reserve Bank (SARB) against international standards and they are used as a yardstick for supervising the performance of banks.

The BIS has issued guidelines on the sound management of liquidity risk for banking institutions. These practices, which comprise 14 principles designed to ensure sound liquidity management, are set forth in two papers called Sound practices for managing liquidity in banking organisations (BIS, 2000) and The joint forum: the management of liquidity risk in financial groups (BIS, 2006c). These quantitative and qualitative standards and guidelines, together with the Basel Core Principles, serve as the only guidelines on the regulatory treatment of liquidity risk. These guidelines and practices do not quantify liquidity risk and therefore do not draw sufficient attention to the severity posed by inadequate liquidity risk management. Berger and Bouwman (2006:1) support this view and note that no comprehensive measure for bank liquidity risk currently exists. For this reason they attempted to develop a comprehensive measure and explored the relationship between bank liquidity creation and capital. Other insights are provided by Belousov and Bobyshev (2005:3) who explain how liquidity risk should be incorporated into overall market risk measurement while Kronseder (2003b) explores the possibility of applying a 'liquidity-at-risk' measure to complement current measures. Both Kronseder (2003a:4) and the BIS (2006c:6) have explicitly identified and discussed the sources of liquidity risk. The Hong Kong Monetary Authority (2004:52), among others, has identified early warning signals for liquidity problems. Despite the importance of measuring and managing liquidity risk correctly, the regulatory treatment of liquidity risk under Basel II, however, remains vague and inadequate. The term 'liquidity risk' appears only three times in the Basel II Accord of almost 350 pages and no capital charge (Pillar 1) for liquidity risk is proposed (BIS, 2000:1).

The failure of many banks as a result of liquidity crises, the exposure of banks to liquidity risk on a daily basis and the uncertain treatment of liquidity risk under Basel II has prompted the following questions:
- 'Should regulators require a capital charge for liquidity risk?' and

- 'How should liquidity risk be treated from a regulatory perspective under Basel II, given current practices in the management and measurement of liquidity risk?'

Inadequate liquidity risk management could be calamitous for banks since liquidity crises usually occur - like most risks - without warning. This article aims to explore current practices of the management and measurement of liquidity risk and to propose guidelines for effective liquidity risk regulation in South Africa. In addition, recommendations regarding the regulatory treatment of liquidity risk in South Africa under Basel II by the South African regulator, the Bank Supervision Department (BSD) of the SARB, are also provided.

The article is structured as follows: Section 2 provides the context for the management of liquidity risk by briefly describing Basel II and reviewing some of the recent literature regarding the regulation of liquidity risk.

Section 3 describes the methodology used to analyse liquidity risk in South Africa in order to provide conclusions and recommendations on the regulation thereof. The main analytical findings are presented in Section 4 and Section 5 discusses the major findings along with policy implications. Section 6 concludes the article.

\section{2}

\section{Conceptual framework}

The Basel Committee for Banking Supervision (BCBS) was established by the Central Bank Governors of the Group of Ten countries at the end of 1974 as a result of serious turbulence in international currency and banking markets (Lachapelle \& Lenormand, 2007:5). This turbulence was partly caused by the collapse of the Bretton Woods system of fixed exchange rates.

During the early 1980s the BCBS became concerned that the capital reserves of the main international banks were deteriorating just when international risks, particularly those in comparison with heavily indebted countries, were growing (Styger \& Vosloo, 2005:1). The BIS (1999:4) adds that, for this reason, most of the BCBS time was devoted to capital adequacy and stronger convergence of the 
measurement of global capital adequacy. With a capital buffer against unforeseen losses, the BCBS argued that the risk of crises in the banking system would be reduced and the stability of the system would increase (Finansinspektionen, 2005:3).

The result was the materialisation of a broad consensus on a weighted approach for the measurement of risks for both on- and offbalance-sheet activities and the identification of the need for a multinational Accord for the implementation thereof (Styger \& Vosloo, 2005:1). This led to an accord titled International convergence of capital measurement and capital standards (BIS, 1988). This document was intended to level the playing field in international banking by addressing geographic inequality in regulation and to establish consistent minimum regulatory capital requirements for banks (Filenet, 2007:2) and has become known as the Basel Capital Accord, or the 1988 Accord. A minimum regulatory capital standard for member countries of 8 per cent of their risk-weighted assets was introduced in the accord by the end of 1992 (Oesterreichische Nationalbank, 2007:2). This framework has been progressively introduced in member countries since 1988, as well as in practically all other countries with active international banks (Mendoza \& Stephanou, 2005:3).

The 1988 Accord was not intended to be static, but to evolve over time and, for this reason, the BIS issued a proposal in June 1999 for a new capital adequacy framework to replace the 1988 Accord (Shadow Financial Regulatory Committees (SFRC), 1999:1). Cognos (2003:1) noted that the rationale for the new framework came from the significant changes to approaches in financial markets, banking, risk management and general management practices since 1998. The refinement of this proposal (BIS, 2007b:3) has been taking place ever since which has concluded in the release of the comprehensive version of the New Capital Framework in June 2006, called International convergence of capital measurement and capital Standards, known as Basel II (BIS, 2006b).

The purpose of Basel II is to promote world-wide financial stability by co-ordinating supervisory definitions of capital, risk assessments and standards for capital adequacy across countries (BIS, 1999:9). In addition, a bank's capital requirements were to be linked systematically to the risk level of its activities, including various off-balance sheet forms of exposure (Cognos, 2003:1). Basel II was designed to improve the way in which regulatory capital requirements reflect fundamental risks and to provide better coverage of the financial innovation that has occurred in recent years (BIS, 2007b:3). The changes from the 1988 Accord were aimed at rewarding the advancements made in the field of risk measurement and providing incentives for improvements to continue (SFRC, 1999:2). In other words, Basel II intends to bring a greater emphasis to risk measurement and management practices in banks and to better align capital reserves with actual risk exposures (Filenet, 2007:2). Van Roy (2005:7) argues that the Basel II Accord is more risk-sensitive than the previous Accord.

Basel II consists of three pillars, namely (BIS, 1999:6):

1) Pillar 1: Minimum regulatory capital requirements - the minimum level of regulatory capital requirements. Pillar 1 seeks to develop and expand on the standardised rules as contained in the 1988 Accord and sets out minimum capital requirements only for credit, market and operational risk.

2) Pillar 2: The supervisory review process - the supervisory review of a bank's capital adequacy and internal assessment processes, including its ICAAP.

3) Pillar 3: Market discipline - the effective use of market discipline to strengthen disclosure of information by banks and to encourage safe and sound banking practices.

The BIS believes that these three elements collectively are the essential pillars of an effective capital framework (Van Roy, 2005:7). Banks and other interested parties have welcomed the three-pillar approach.

Despite the lack of detail regarding the regulatory treatment of liquidity risk in Basel II, the BIS (1992:3) stated that the management and measurement of liquidity are considered to be among the most important activities undertaken by banks. A bank must assure itself that it can meet its obligations when they become 
due in order to reduce the probability of liquidity problems. In addition, a bank's liquidity position determines the time that it has available to address problems even when such problems originate in other areas of the bank. Since 1992, when the BIS published a paper called A framework for measuring and managing liquidity, the BIS focussed on enhancing the way in which international banks manage their liquidity on a worldwide basis. This paper is based on the presumption that the supervision of liquidity risk is most effective if it is based on regular interaction between banks and their regulators (BIS, 1992:1).

However, since publication, technological and financial innovations have provided banks with new and different ways of funding their activities and managing their liquidity. Banks' declining ability to rely on core deposits, along with increased dependence on wholesale funds and the global financial market turmoil in the mid to late $1990 \mathrm{~s}$, profoundly changed views on liquidity. A combination of all these changes left banks facing new challenges regarding the management and measurement of liquidity risk. For this reason the BIS published a paper in 2000 which served as an update of the 1992 paper and was called Sound practices for managing liquidity in banking organisations (BIS, 2000). This paper sets out 14 key principles as recommendations to banks in their management and measurement of liquidity risk. Principles 1 to 4 deal with the establishment of a structure for the management of liquidity risk; Principles 5 to 7 deal with the management and measurement of a bank's net funding requirements; Principle 8 with the management of market access and Principle 9 with contingency planning; Principles 10 and 11 describe the management of foreign currency liquidity; Principle 12 deals with the internal controls for effective liquidity risk management; Principle 13 with the role and importance of public disclosure and reporting of liquidity risk; and Principle 14 deals with the role of regulators.

In 2006 the BIS published a further paper called The management of liquidity risk in financial groups (BIS, 2006c) which focused on best practices of managing liquidity risk in multinationals which were engaged in banking, insurance and securities activities.

In March 2007 the Institute of International Finance (IIF) published a paper named Principles of liquidity risk management (IIF, 2007). This paper was based on work done by a special committee that was established by the IIF late in 2005 and represented about 40 of the largest banks in the world. The objective of the Special Committee was to develop a perspective and provide recommendations on liquidity risk measurement, monitoring, management and governance at financial institutions (Weinberg, 2007:2). The Special Committee made 44 recommendations for the sound management of liquidity risk. The first 13 recommendations address the governance and organisational structure for managing liquidity risk, while recommendations 14 to 30 address the analytical framework for measuring, monitoring and controlling of liquidity risk. Recommendations 31 to 44 address liquidity stress testing and contingency planning.

It is important that the Basel Core Principles be considered when developing an approach for the regulation of liquidity risk, since the BSD is assessed by the International Monetary Fund (IMF) in terms of its compliance with these Principles.

Although these articles may provide valuable insights for regulators regarding the regulation of liquidity risk, liquidity risk regulation is not explicitly discussed. For this reason, Sharma (2004:5) argues that liquidity risk has been too long overlooked as a focus of attention for regulatory reform. This view is supported by the BCBS who issued a press release in October 2007 emphasising the need for 'strengthening supervision and risk management practices in areas like liquidity risk' after the liquidity crunch experienced by the large UK building society, Northern Rock, in September 2007 (BIS, 2007a:1).

Since South Africa forms part of the global economy, it is inevitably affected by global developments. While keeping in mind the turbulent financial markets that have been prevalent across the world over the past couple of years, including liquidity problems experienced, and the fact that South Africa adopted the Basel Accord, a study around the regulation on liquidity risk is not only pertinent, but necessary. 
3

\section{Methodology}

To explore current practices in South Africa critically and propose guidelines for effective liquidity risk regulation, a quantitative analysis on liquidity risk in the South African banking system was conducted. A liquidity risk questionnaire was presented to various bankers and ex-bankers in order to assess whether it is prudent for regulators, in their view, to require banks to hold capital for liquidity risk. The questionnaire was tested on a number of bankers before it was sent to eight experienced professionals from the major South African banks including liquidity risk managers, treasurers, ex-treasurers, market risk managers and analysts. Although it is acknowledged that eight professionals does not constitute a large enough sample to make meaningful conclusions, the purpose of the questionnaire was not to draw definitive conclusions, but rather to gauge different views among respondents. The analysis of the liquidity risk questionnaire was not done for a specific period analysed, but rather as a general point-in-time questionnaire that covered historical events and current and future views on liquidity risk in South Africa.

To determine the state of funding liquidity (and therefore the degree of funding liquidity risk in a country's banking sector) the analysis of an aggregated balance sheet (of all the banks in a particular country) could prove useful. Data were gathered from the SARB website where all $\mathrm{DI}^{3}$ returns submitted by the banks to the SARB are available in an aggregated format. Data from the DI 100 (regulatory balance sheet) and DI 300 (liquidity risk return) for 60 months (from May 2002 to April 2007) for the aggregate banking sector was applied. The liabilities and assets of the DI 100 were analysed separately in terms of term structure and composition before a conclusion was reached regarding a possible funding mismatch of the South African banking sector (SAbs) (aggregated).

The analysis conducted on the aggregated DI 300 used only lines 1-7 of the return, or the contractual mismatch (SARB, 2007a). The reason is that different banks apply different ALCO models and apply different assumptions to derive their respective theoretical mismatch figures, whereas contractual mismatches are not subject to any assumptions. The analysis on the DI 300 was conducted to determine whether results would support those from the analysis done on the DI 100.

An analysis on the aggregated figures of the SAbs, however, is not indicative of exactly where liquidity risk resides. The DI 900 return (completed and submitted to the SARB on a monthly basis), indicates the institutional and maturity breakdown of liabilities and assets. Data were collected from the DI 900 for five quarterly periods from April 2006 to April 2007 and not for the same period of time as was the case for the analyses on the DI 100 and DI 300 returns. The reason was to avoid the onerous exercise of calculating eleven ratios for eleven institutions for sixty months. It should be noted that each return represents a datum only for the month in which it was submitted.

The analysis conducted on the DI 900 was similar to the analysis done by Saayman (2003), where the ratios used fell perfectly into the paradigm of this article. The liquidity positions of 10 different banks as well as that of the total banking sector in South Africa were calculated. The calculation included three large banks from Peer Group $1,{ }^{4}$ one bank from Peer Group 2, ${ }^{5}$ three banks from Peer Group $3^{6}$ two banks from Peer Group $4^{7}$ and ons from Peer Group $5^{8}$. Five months of information was used, namely April 2006, July 2006, October 2006, January 2007 and April 2007.

The most widely used ratios to measure the banks' liquidity positions include the loan-todeposit ratio, the loan-to-liability ratio, the liquid-asset-to-liability ratio and the volatile liability dependency ratio (Saayman, 2003:5). The liquidity ratios were calculated as follows:

i The loan-to-deposit ratio. The following loan categories were included in the analysis, namely: loans and advances within the same group (line 101 column 3), instalment debtors (line 113 column 3), mortgage advances (line 118 column 3), credit card debtors (line 126 column 3), other overdrafts and loans to the public sector (line 154 column 3) and other private sector loans and advances (line 163 column 3). Deposits include deposits over all terms 
and to all counterparties (line 1 column 8) (South Africa (SA), 2000:228-238). A higher loan-to-deposit ratio indicates lower liquidity (Olson Research (OR), 2000:12). From the definition, a loan-to-deposit ratio of one or more would indicate extremely low, or even negative liquidity.

ii The loan-to-liability ratio. The same loan categories used to calculate the loan-todeposit ratio were used. Total liabilities were calculated as the sum of total funding-related liabilities to the public (line 63 column 4), outstanding liabilities on behalf of clients (line 64 column 4) and other liabilities (line 65 column 4) (SARB, 2007a). A higher ratio indicates lower liquidity because this ratio indicates the contribution of loans to total liabilities (Saayman, 2003:5).

iii The liquid-asset-to-liability ratio. All items that can easily be turned into cash were viewed as liquid assets (Saayman, 2003:5). These liquid assets include central bank money and gold (line 86 column 3), SA bank group funding, including negotiable certificates of deposit (NCDs) (line 96 column 3), South African interbank group funding, including NCDs (line 102 column 3 ), loans granted under resale agreements (line 109 column 3), liquid bills, notes and acceptances (line 131 column 3), deposits with and advances to the SARB (line 142 column 3), deposits with and advances to South African banks (line 143 column 3), marketable South African government stock (unexpired maturity of up to three years), other public sector interest-bearing securities (line 187 column 3) and debentures and other interest-bearing security investments (line 194 column 3) (SA, 2000: 228:238). Although a lower ratio indicates lower levels of liquidity, it can be expected in South Africa to be around 0.20 due to the liquid asset reserve requirements that are 5 per cent of banks' reduced liabilities (Saayman, 2003:5).

iv The volatile liability dependency ratio. The volatile dependency ratio is the difference between volatile liabilities and liquid assets, relative to earning assets (Saayman, 2003: 5). It measures the relationship between long-term earnings assets and net short- term funds (OR, 2000:13). Liquid assets were calculated as described above, while the volatile liabilities were calculated as the sum of cash managed, cheques and transmission deposits (line 1 column 1), other demand deposits (line 1 column 2), short-term savings (line 1 column 3 ) and other short-term deposits (line 1 column 4). Earning assets are calculated as the sum of deposits, loans and advances (line 95 column 3) and the investments (line 176 column 3) of a specific bank. A negative value indicates more liquid assets than volatile liabilities (OR, 2000:13).

In addition to these general measures of liquidity, liability liquidity measures were also calculated. Liability liquidity refers to the bank's ability to raise liquid funds through borrowings in the money market (Saayman, 2003:4). Four liability liquidity ratios for the 10 selected South African banks were calculated, being the total-deposit-to-totalliability ratio (as a measure of the bank's asset composition), the equity-to-total-assets ratio (as a measure of the capital base) and the percentage composition of deposits (Saayman, 2003:6).

1 The total-deposit-to-total-liability ratio. The total deposit value from the DI 900 returns (line 1 column 8) was used and the total liabilities were calculated as above. Higher ratios indicate more reliance on deposits (Saayman, 2003:6).

2 The equity-to-total-asset ratio. The equityto-total-asset ratio was calculated by dividing the capital and reserve funds of the bank (line 71 column 1 ) by the total assets of the bank (line 224 column 3) (SARB, 2007a). A lower equity-to-total-asset ratio indicates that capital is applied more effectively (Saayman, 2003:6).

3 The percentage composition of deposits. In calculating the percentage composition of deposits, the different types of deposits were determined relative to the total deposit value (line 1 column 8 ) of each bank much the same as the percentage composition of liabilities calculated for the aggregated banks balance sheet. Cash managed, cheque and transmission deposits (line 1 column 1) and other demand deposits 
(line 1 column 2) were added to calculate the value of total demand deposits. Shortterm deposits are the sum of short-term savings (line 1 column 3 ) and other shortterm deposits (line 1 column 4). Mediumterm deposits are calculated as the sum of medium-term savings (line 1 column 5) and other medium-term deposits (line 1 column 6) and long-term deposits are indicated separately in the DI 900 (line 1 column 7).

4 Net liquid assets. Net liquid assets are calculated as the difference between liquid assets and volatile liabilities. Liquid assets and volatile liabilities were calculated in the same way as discussed above. A positive liquid asset value highlights the importance of assets as a source of liquidity for these banks.

These calculations, however, do not explicitly describe liquidity risk or the perceptions thereof in South Africa whilst clearly this need exists. Because of the difficulty in measuring and observing liquidity risk, a short questionnaire comprising 11 questions was compiled in order to gauge different views on liquidity risk and its possible regulation ${ }^{9}$. The questionnaire was tested on a number of bankers before it was sent to eight experienced professionals including liquidity risk managers, treasurers, ex-treasurers, market risk managers and analysts. Respondents answered the questionnaire in writing after which answers to questions were discussed with them. The questionnaire also served as the basis for structured telephone interviews conducted with some respondents. The responses of all the respondents were combined to represent the results.

\section{4}

\section{Results}

\section{Analysis of the aggregated banks balance sheet}

\section{Liabilities}

Funding-related liabilities had the largest contribution to total liabilities, averaging 78.9 per cent over the 60 months analysed. Second largest was other liabilities and trade creditors (OLTC) that made up an average of 12.8 per cent. Acknowledgement of debt (DA) was the smallest component of total liabilities and averaged only 0.08 per cent (capital made up the remaining 8.26 per cent. Therefore, any movements in funding-related liabilities to the public automatically have the greatest impact on total liabilities.

The composition of the term structure of liabilities showed that the aggregate SAbs balance sheet is, as expected, dominated by short-term liabilities that made up an average of 59.4 per cent of total liabilities and capital over the period analysed. Medium-term liabilities averaged 17.2 per cent and long-term liabilities averaged 15.1 per cent over the period. Capital was the smallest component of total capital and liabilities and averaged 8.3 per cent. This composition is illustrated by Figure 2.

Figure 1 shows that general growth figures for all of the categories of liabilities did not show clear trends. Short-term liabilities increased at an average annual rate of 14.5 per cent, medium-term liabilities at an average annual rate of 19.5 per cent and long-term liabilities at an average annual rate of 20.1 per cent over the period analysed. Even though medium and long-term liabilities have been growing at a significantly higher rate than short-term liabilities, this trend should remain for many years to reduce the domination of short-term liabilities on the balance sheet. Growth in capital did not match growth in total liabilities and grew at an average annual rate of 11.7 per cent, whereas total liabilities increased at an average annual rate of 16.0 per cent over the five years analysed.

\section{Assets}

Loans and advances make up the biggest portion of total assets at 77.6 per cent over the period analysed while trading and investment positions (the second largest component) averaged 17.0 per cent. Other components cumulatively contributed to 5.4 per cent of total assets and are therefore considered negligible. The composition of assets is illustrated by Figure 2 while growth in assets is illustrated by Figure 1.

Total assets (as with total liabilities) increased over the period. Loans and advances increased at an average annual rate of 15.6 per cent while investment and trading positions 
increased at an average annual rate of 29.0 per cent. Although slightly higher, the growth in these two items is in line with the growth rate in total assets, at 15.6 per cent. The growth rate of investment and trading positions is distorted by a large increase which occurred in 2002/03.

Figure 1

Selected liabilities and assets average growth: 2002-03-2006/07.

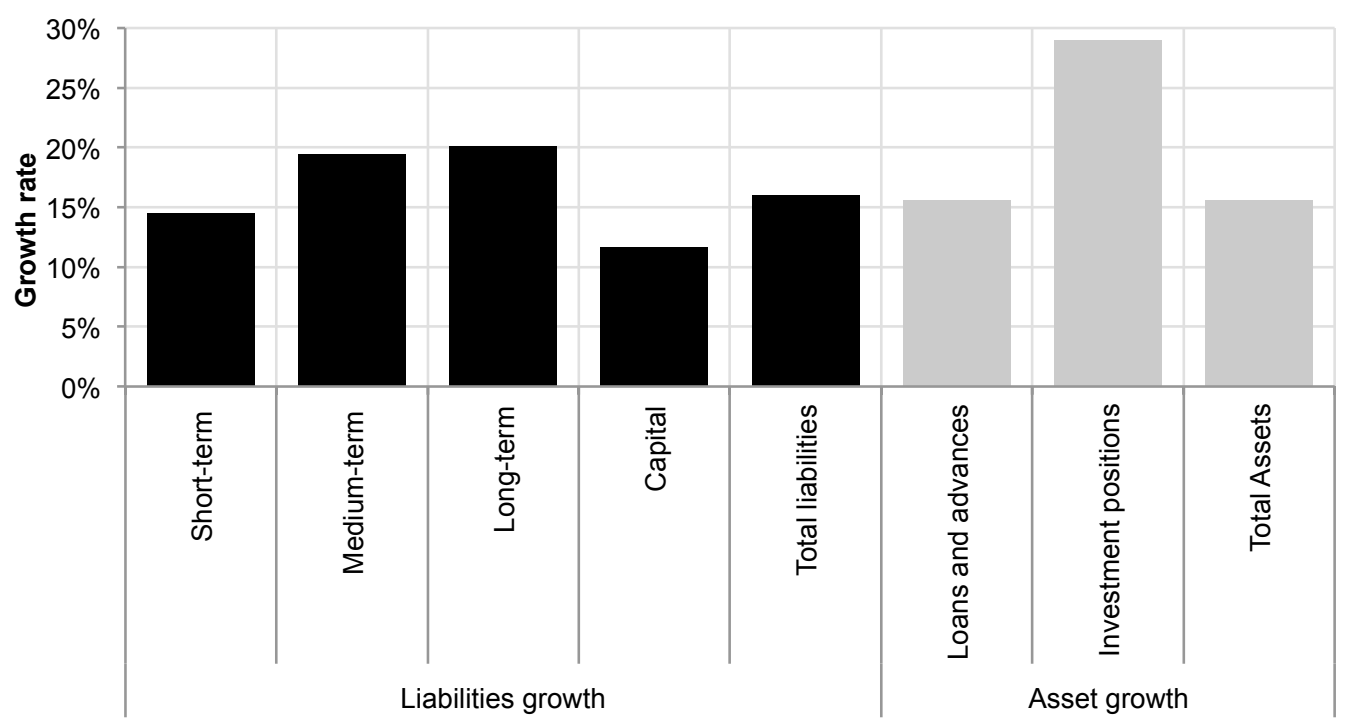

The term structure of assets is not divided into buckets as is the case for liabilities, but it can be assumed that a large majority of loans and advances are long-term assets according to the definition used for liabilities, i.e. longer than 6 months. When considering that mortgage loans as well as asset and vehicle financing are included in this figure, short-term loans can reasonably be expected to contribute a relatively small portion of loans and advances. When making such assumptions, it becomes apparent that the South African banks' aggregate balance sheet may be extremely short-funded. This implies that long-term assets are funded by short-term liabilities, creating a liquidity mismatch, hence reinforcing the prevalence of liquidity risk. Although it may be argued that the same liquidity risk prevails (due to the type of business that banks do), the analysis of an aggregated banks' balance sheet in South Africa proved the existence of elements of significant liquidity risk.

Figure 2

Composition of assets and liabilities
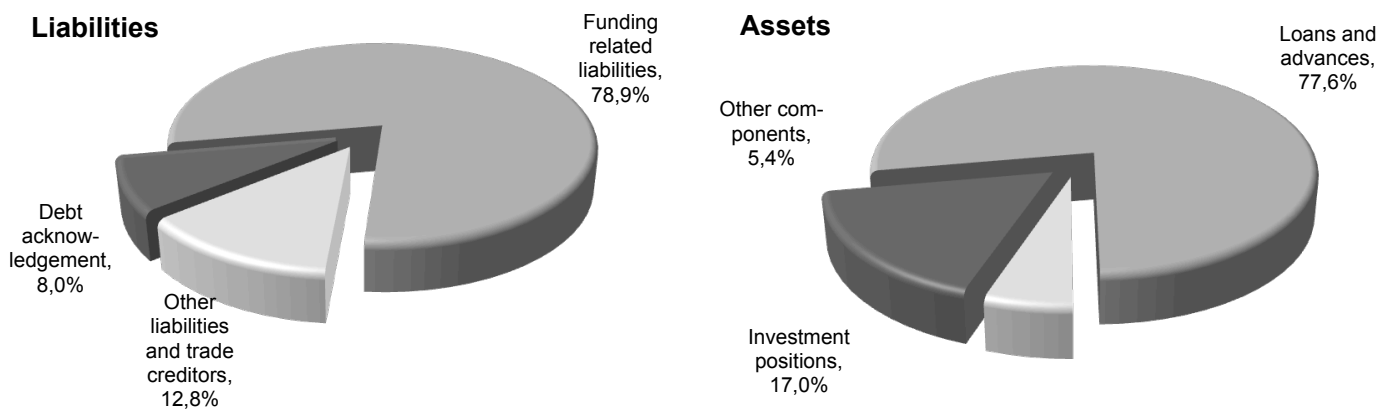


\section{Analyses of the aggregated banks' liquidity risk returns}

From the analysis conducted on the DI 300 liquidity risk returns for the SAbs, the existence of significant liquidity risk from balance sheet analyses was confirmed. A conclusion that may be drawn from this analysis is that short-term liabilities are increasingly used to fund long-term assets, which represents significant growing liquidity risk in the SAbs. Table 1 illustrates that, although assets and liabilities seem well- matched in percentage terms, the small percentage differences translate to large nominal mismatches, demonstrating this liquidity risk. This can be seen where a small percentage difference in the $0-31$ days bucket of 0.24 per cent translates to a R373 million difference in nominal terms. An analysis on aggregated figures does not, however, indicate exactly where the liquidity risk originates. For this reason, an analysis was conducted on liquidity risk in various banks in South Africa.

Table 1

Liquidity mismatch in percentage and nominal terms

\begin{tabular}{|c|c|c|c|c|c|c|}
\hline & & \multicolumn{4}{|c|}{ DAYS } & \multirow[b]{2}{*}{ Total } \\
\hline & & $0-31$ & $32-60$ & $61-91$ & $92-181$ & \\
\hline \multirow{3}{*}{$\begin{array}{c}\text { Matching of assets \& } \\
\text { liabilities (\%) }\end{array}$} & Average assets & $77.2 \%$ & $7.5 \%$ & $6.6 \%$ & $8.6 \%$ & $100 \%$ \\
\hline & Average liabilities & $77.4 \%$ & $8.8 \%$ & $5.9 \%$ & $7.8 \%$ & $100 \%$ \\
\hline & Mismatch & $-0.2 \%$ & $-1.3 \%$ & $0.7 \%$ & $0.8 \%$ & $0 \%$ \\
\hline \multirow{3}{*}{$\begin{array}{c}\text { Matching of assets \& } \\
\text { liabilities (nominal } \\
\text { Rmn) }\end{array}$} & Average assets & 533.2 & 51.4 & 44.9 & 59.4 & 688.9 \\
\hline & Average liabilities & 907.1 & 102.5 & 68.7 & 91.4 & 1169.7 \\
\hline & Mismatch & -373.8 & -51.1 & -23.8 & -32.0 & -480.7 \\
\hline
\end{tabular}

\section{Analyses of banks' DI 900 returns}

The results for the general measures of liquidity and liability liquidity provide the following insight: In terms of the loanto-deposit ratio, a higher ratio indicates lower levels of liquidity. The total banking sector had a loan-to-deposit ratio of between 0.85 and 0.90 meaning that liquidity was a relatively large risk in the South African banking system. Only one bank was a prominent outlier, indicating an extremely large level of liquidity risk.

The results for the loan-to-liability ratio differed between banks. Again, a larger ratio presents lower levels of liquidity. In general, the loan-to-liability ratios were at relatively low levels, meaning that liquidity levels were relatively high. Again, only one bank had a relatively low level of liquidity.

For the liquid assets-to-liability ratio, most of the banks that were analysed displayed low levels of liquidity as most of them had quite low ratios. For the liquid assets-to-liability ratio, four banks had exceptionally good ratios. For the total banking sector, this ratio is quite low, but still around the expected 0.20.
A negative value for the volatile liability dependency ratio indicates more liquid assets than volatile liabilities. The total banking sector was found to have more liquid assets than volatile liabilities and nine of the ten banks that were analysed had negative values. Only one bank had more volatile liabilities than liquid assets.

A higher total-deposit-to-total-liability ratio indicates a higher dependency on deposits. This ratio was found to be very high in the SAbs. Only two banks had low dependencies on deposits. All the other banks that were analysed had a large dependence on deposits.

The total banking sector applies its capital effectively because it has a low equity-to-totalasset ratio. The banks analysed were divided with six banks applying capital effectively and four not as effectively.

The composition of deposits for the total banking sector revealed similar results to the analysis conducted on the total banks' balance sheet. A significant portion of deposits are made up of demand deposits and short-term deposits for the total banking sector. Five banks displayed similar characteristics to the whole 
banking sector, whereas the composition of deposits for the remaining banks differed from bank to bank. But, as mentioned previously, it would be extremely difficult to receive 30-year deposits that would fund 30-year loans.

The main finding from conducting liquidity ratio analyses on different banks is that liquidity risk varies from one bank to the next, meaning that a universal Pillar 1 capital charge for all banks would not make sense, but that liquidity risk should rather be assessed by regulators on a case-by-case basis under Pillar 2 of Basel II. It was also found that the SAbs relies heavily on demand and short-term deposits. This confirmed the results obtained from the analyses conducted on banks' aggregated figures, i.e. that the SAbs is extremely short-funded.

\section{Liquidity risk questionnaire}

In general, liquidity risk is not perceived as a threat in South Africa, but banks and regulators are well aware of the potential danger that it holds for individual banks and the banking system as a whole. For this reason, liquidity risk is actively monitored and managed. Liquidity crises at the individual bank level as well as on a systemic level could be triggered by a wide variety of internal and external events as well as internal practices of banks.

Banks have contingency funding plans in place. The details of such plans, however, differ greatly between banks. In response to the question posed on whether a liquidity crisis will spread from smaller banks to larger banks (the way that the Saambou and $\mathrm{BoE}^{10}$ crises spread), respondents felt that a liquidity crisis in South Africa will not necessarily spread from smaller banks to bigger ones, but it may spread to smaller banks if big banks experience liquidity problems. A systemic liquidity crisis may be caused by a build-up over an extended period of time, and not necessarily by a single event. It is considered that a wide variety of events can cause a systemic liquidity crisis in South Africa.

Liquidity risk in South Africa seems to be well mitigated by banks as they make use of a wide variety of instruments and strategies to mitigate liquidity risk. Emphasis was placed on the fact that active and effective management and monitoring of liquidity risk are considered to be the most important liquidity risk mitigants. The South African banking system is large and stable, well regulated and also adequately capitalised. These three factors are considered to be the main liquidity risk mitigants in the South African banking system. Although major structural changes have taken place in the South African banking system since the crises in 2001/02, a liquidity crisis cannot really be prevented because it typically occurs without warning. The crux of these structural changes was that legislation in banking specifically has tightened significantly since 2002, meaning that banks operate in a better-regulated and more stable environment. In addition, there are fewer small banks in the South African banking sector than before, when liquidity risk typically originated from these smaller banks.

The general view amongst respondents was that it would not make sense to hold capital for liquidity risk because capital is seen as being expensive and restrictive and not an effective mitigant for liquidity risk. By requiring banks to hold capital for liquidity risk, the South African banking system also runs the risk of being over-regulated. Further difficulty regarding such a capital charge includes the way in which it should be calculated. Respondents felt that it would be extremely difficult to calculate such a capital charge in a sensible manner. For these reasons, a Pillar 2(b) capital charge under Basel II would be more sensible to regulate liquidity risk. The objective of such a capital charge would not be to cover liquidity risk per se, but rather to impose a 'fine' on banks that do not manage and measure liquidity risk prudently in the regulator's opinion until such time as it is deemed to be managing and measuring liquidity risk prudently.

\section{5}

\section{Discussion}

This section discusses and summarises the main findings of this study.

\section{Process for reviewing liquidity risk}

Although Pillar 2 reviews a variety of other risks and not only liquidity risk, it is proposed that the liquidity risk part of such reviews should be conducted on the basis of a questionnaire used to determine possible gaps 
between banks' practices and prescribed criteria regarding the management and measurement of liquidity risk. Accordingly, banks would have to provide responses to a standard exhaustive questionnaire on liquidity risk after which the BSD evaluates banks' responses to the questionnaire in order to determine possible gaps between banks' practices and prescribed criteria. These gaps would then be addressed by means of an on-site visit to the bank by a BSD team.

It is important to note that such an approach has a constraint in terms of the substantial amount of work that would have to be done on the regulation of liquidity risk by both regulators and banks. Therefore resource constraints and the cost versus the benefit of such an approach would have to be considered carefully.

\section{Regulatory capital for liquidity risk}

Findings from the liquidity risk questionnaire indicate that capital is not considered an effective instrument for regulating liquidity risk, because when a bank experiences liquidity problems, the best way to cope is to have a stock of liquid assets or cash. The allencompassing conclusion of this article is that capital would not be an effective mitigant for liquidity risk for a number of reasons. Liquidity risk differs from bank to bank and a general capital charge for all banks may not be sensible, therefore liquidity risk should be analysed on a bank-by-bank basis. In other words, capital could be charged for liquidity risk under Pillar 2(b) of Basel II. Such a capital charge would not serve the purpose of covering losses resulting from liquidity risk, but would instead impose a penalty on banks that are deemed to manage and measure liquidity risk imprudently. Such a penalty would typically be quite small but would serve as an incentive for banks to improve their management and measurement techniques to the desired level as set out by prescribed criteria.

The criteria that should be used for determining whether banks measure and manage liquidity risk prudently should be of such a nature that the BSD complies with Revised Basel Core Principle 14: Liquidity Risk in regulating liquidity risk. In addition, it should align the criteria used to the 14 Principles for the sound management of liquidity as prescribed in the article called Sound practices for managing liquidity in banking organisations (BIS, 2000). The criteria for sound liquidity risk management could be incorporated into the questionnaire that may be used to assess liquidity risk under Pillar 2(b) of Basel II as part of the supervisory review and evaluation process (SREP) ${ }^{11}$ process conducted by the BSD.

A simple scoring approach for each question $(3=$ satisfactory, $2=$ average and $1=$ unsatisfactory) could be helpful in assessing the quality of liquidity risk management and measurement as well as identifying possible gaps between banks' practices and prescribed guidelines that should be addressed by a bank. The basis for determining a capital charge may be based on average scores obtained from banks answering the SREP section of the questionnaire. For example, a certain increment of capital could be charged for each 0.05 under the perfect score, which would be three. This may not be a scientific way in determining a Pillar 2(b) capital charge, but would make sense if applied consistently.

\section{An internal models approach for liquidity risk}

The BSD should not prescribe to banks which methods to use to report their liquidity risk, because banks differ in terms of size and sophistication. For this reason, banks should be allowed to follow an internal models approach for liquidity risk whereby banks are, subject to regulatory approval, allowed to use their own internal liquidity risk measures to report liquidity risk to the BSD. This approach is similar to the approach followed by the Bundesbank in Germany.

\section{A liquidity risk questionnaire}

A liquidity risk questionnaire could be drafted according to which banks' liquidity risk management and measurement is assessed in terms of the Sound principles for managing liquidity risk and the Basel Core Principles. One questionnaire could be used for both assessing the quality of banks' liquidity risk management and measurement in terms of an SREP and approval application of an internal 
models approach for liquidity risk. Alternatively, the questionnaire could be divided into two clear sections whereby all banks are required to answer the SREP or Pillar 2(b) section, and only banks applying for the use of an internal models approach for liquidity risk are required to complete the second section.

\section{Regulatory liquidity risk policy framework}

A further conclusion of this article is that the South African banking regulator should publish a framework in which its approach to regulating liquidity risk is described in detail. Some aspects that should be included in such a document include a widely-accepted definition for liquidity risk and guidelines/minimum standards for measurement and management techniques for liquidity risk and the process that will be followed under Pillar 2 of Basel II.

\section{Liquidity risk mitigants}

If the BSD is concerned about the level of potential liquidity risk in the South African banking system, it could consider having the additional instruments that are eligible as collateral as described by SARB (2007b) included as instruments eligible for liquid assets reserve requirements. The exact impact of doing this is uncertain, but will probably lead to banks holding a larger amount of liquid assets over and above the 5 per cent requirement. This would mean that the SAbs will be better protected against and better equipped to deal with liquidity problems. The process for including these instruments as liquid assets will be a tedious one, because it will mean that the South African Banks Act $^{12}$ will have to be amended to include these instruments, as the Act defines only specific instruments that may be held for this.

An additional mitigant for liquidity risk may be that the BSD requires banks to report their liquidity risk on a more frequent basis than the current monthly reporting. Market risk is currently reported on a daily basis simply because of the ever-changing environment. Liquidity risk can also be considered to be an ever-changing risk, which will warrant more frequent reporting.

\section{Conclusions}

The results of this study indicate that capital would not be an effective mitigant for liquidity risk for several reasons. Liquidity risk differs from bank to bank and a general capital charge for all banks may not be feasible. Instead, liquidity risk should be analysed on a bank-by-bank basis. Capital could thus be charged for liquidity risk under Pillar 2(b) of Basel II. By requiring banks to complete a standard, exhaustive liquidity risk questionnaire and then awarding banks scores for each question based on the level of satisfaction of such answers, a possible capital charge could be derived. Capital could then be charged in a standardised manner according to banks' average scores obtained. Such a capital charge would not serve the purpose of covering losses resulting from liquidity risk, but would instead impose a penalty on banks that are deemed to manage and measure liquidity risk imprudently. Such a penalty would typically be quite small, but would serve as an incentive for banks to improve their management and measurement techniques to the desired level as set out by prescribed criteria. The criteria that should be used for determining whether banks measure and manage liquidity risk prudently should be of such a nature that the BSD of the SARB complies with Basel Core Principle 14: Liquidity Risk in regulating liquidity risk. It should also align the criteria used to the 14 Principles for the sound management of liquidity as prescribed by the BIS and the IIF.

Although the findings of this article deal largely with the qualitative nature of liquidity risk management, the BIS has introduced more quantitative measures to reinforce the qualitative approach in December 2010 as part of the new Basel III Accord. The quantitative measures include prescribed amounts that should be achieved for banks' liquidity coverage and stable net funding ratios. Future research could include further studies on the quantitative side of liquidity risk management and supervision and the link between quantitative and qualitative measures in pursuit of a strong and resilient approach to liquidity risk regulation. 


\section{Endnotes}

1 Article from Master's dissertation of the same title (December 2007). The opinions and views expressed herein are those of the authors and do not necessarily represent those of either the South African Reserve Bank (SARB) or North-West University. At the time of publication of this article the SARB would have decided on an approach for the regulation of liquidity risk which may not be similar to that contained in herein.

2 The BIS has, since the completion of the paper upon which this article is based, finalised its approach to the regulation of liquidity risk in a paper titled Basel III: International Framework for Liquidity Measurement, Standards and Monitoring in December 2010.

3 DI returns were regulatory returns in which banks reported to the BSD, but these do not exist anymore as they were replaced by BA returns with the inception of Basel II. The basis of this change was simply to bring it in line with South African banking legislation, or the Banks Act, hence the BA-suffix. The DI-suffix was for Deposit-taking Institution.

4 Peer Group 1 consists of banks that are considered to be systemically important to the South African financial system.

5 Peer Group 2 consists of foreign branches of banks with trading operations.

6 Peer Group 3 consists of banks that are involved in micro-financing and/or Islamic banking.

7 Banks that are included in Peer Group 4 are considered to be 'niche banks' or banks that operate in certain niche markets, such as high-value low-volume markets for more affluent clients.

8 Peer Group 5 consists of foreign branches of banks without trading operations.

9 The questionnaire is available from the author on request.

10 Saambou Bank was placed under curatorship following a run on the bank amid fears of insider trading, and bad debts in its micro lending business had put the bank under pressure. BoE Bank was eventually taken over by Nedcor following a run on the bank by depositors amid concerns around its liquidity. In both cases, the share prices of smaller banks were significantly affected as a result.

11 The SREP involves regulators identifying, reviewing and evaluating all risk factors and the relevant control factors associated with each of these risk factors. When conducting a supervisory review and evaluation process, regulators are prescribed by the BIS to do a number of things. These are summarised as follows: review of adequacy of risk assessment an assessment of capital adequacy, assessment of the control environment, a supervisory review of compliance with minimum standards and a supervisory response.

12 The South African Banks Act is the South African banking law with its objective being to provide for the regulation and supervision of the business of public companies taking deposits from the public; and to provide for matters therewith.

\section{References}

BANK FOR INTERNATIONAL SETTLEMENTS, Basel committee on banking supervision (BCBS). 1988. International convergence of capital measurement and capital standards. July. Basel, Switzerland.

BANK FOR INTERNATIONAL SETTLEMENTS, Basel committee on banking supervision (BCBS). 1992. A framework for measuring and managing liquidity. September. Basel, Switzerland. Available at: http://www.bis.org/publ/bcbs10b.pdf [accessed 2007-03-06].

BANK FOR INTERNATIONAL SETTLEMENTS, Basel Committee on Banking Supervision (BCBS). 1999. A new capital adequacy framework. Consultative Paper Issued by the Basel Committee on Banking Supervision. June. Basel, Switzerland.

BANK FOR INTERNATIONAL SETTLEMENTS, Basel committee on banking supervision (BCBS). 2000. Sound practices for managing liquidity in banking organisations. February. Basel, Switzerland.

BANK FOR INTERNATIONAL SETTLEMENTS, Basel committee on banking supervision (BCBS). 2006a. Core principles methodology. October. Basel, Switzerland.

BANK FOR INTERNATIONAL SETTLEMENTS, Basel committee on banking supervision (BCBS). 2006b. International convergence of capital measurement and capital standards: a revised framework. July. Basel, Switzerland.

BANK FOR INTERNATIONAL SETTLEMENTS, Basel committee on banking supervision (BCBS). 2006c. The joint forum: the management of liquidity risk in financial groups. May. Basel, Switzerland. Available at: http://www.bis.org/publ/joint16.pdf [accessed 2007-02-12].

BANK FOR INTERNATIONAL SETTLEMENTS, Basel committee on banking supervision (BCBS). 2007a. Financial market developments and the work of the Basel committee, Press Release issued on the BIS Website. 9 October. Basel, Switzerland. Available at: http://www.bis.org/press/p071009.htm [accessed 2007-10-22].

BANK FOR INTERNATIONAL SETTLEMENTS, Basel committee on banking supervision (BCBS). 2007b. History of the Basel committee and its membership. January. Basel, Switzerland. Available at: http://www.bis.org/bcbs/history.pdf [accessed 2007-05-16].

BELOUSOV, S., \& BOBYSHEV, A. 2005. Handling liquidity risk in market risk modelling: practical experience, PRMIA Risk Management Conference. 20 September. Moscow, Russia. Available at: http://www.gloriamundi.org/picsresources/absb.pdf [accessed 2007-02-13]. 
BERGER, A.N. \& BOUWMAN, C.H.S. 2006. The measurement of bank liquidity creation and the effect of capital. September. Washington DC, United States of America. Available at: http://fic.wharton.upenn.edu/ fic/papers/07/0702.pdf [accessed 2007-02-13].

BIS see BANK FOR INTERNATIONAL SETTLEMENTS.

COGNOS. 2003. Basel II. June. United States of America. Available at: http://www.cognos.com/solutions/ thankyou/basel2.pdf [accessed 2007-07-30].

FILENET. 2007. Basel II: from compliance to competitive advantage. Whitepaper for Banking and Financial Markets. January. Costa Mesa, United States of America. Available at: http://www.filenet.com/English/ Industry_Solutions/Financial_Services/BaselCompliance.pdf [accessed 2007-05-21].

FINANCIAL SUPERVISION COMMISSION. 2005. A consultative paper on liquidity risk management policies for banks. Isle of Man Government. 31 January. Available at: http://www.gov.im/lib/docs/fsc/ Consultative/Banking/s4liquidity.pdf [accessed 2007-02-15].

FINANSINSPEKTIONEN. 2005. Institutions' internal capital adequacy assessment process: assessment of capital adequacy under Basel II. Journal No. 05-5939-350. 26 September. Stockholm, Sweden. Available at: http://www.fi.se/upload/90_English/20_Publications/10_Reports/Report2005_8.pdf [accessed 2007-05-21].

HOGGARTH, G., REIDHILL, J. \& SINCLAIR, P. 2003. Resolution of banking crises: an overview.

Financial Stability Review 2003. Bank of England. December. London, England. Available at: http://www.bankofengland.co.uk-publications-fsr-2003-fsr15art6 [accessed 2007-02-25].

HONG KONG MONETARY AUTHORITY. 2004. Supervisory policy manual: liquidity risk management, version 1. 20 August. Hong Kong. Available at: http://www.info.gov.hk/hkma/eng/bank/spma/attach/LM1.pdf [accessed 2007-02-16].

IIF see INSTITUTE OF INTERNATIONAL FINANCE.

INSTITUTE OF INTERNATIONAL FINANCE. 2007. Principles of liquidity risk management. March. Washington DC, United States of America.

KRONSEDER, C. 2003a. Liquidity risk management: an introduction. 13 May. Credit Suisse First Boston. Boston, United Sates of America. Available at: http://www.gtnews.com/article/4988.cfm [accessed 2007-02-21].

KRONSEDER, C. 2003b. Managing liquidity risk. 20 August. Credit Suisse First Boston. Boston, United Sates of America. Available at: http://www.gtnews.com/article/5125.cfm [accessed 2007-02-21].

LACHAPELLE, E. \& LENORMAND, T. 2007. A whitepaper on Basel II. Veridion Inc. Montreal, Canada. Available at: http://www.veridion.net/Page-Level1/Basel2/BaselII_En_WP.pdf [accessed 2007-07-31].

MENDOZA, J.C. \& STEPHANOU, C. 2005. Credit risk measurement under Basel II: an overview and implementation issues for developing countries. World Bank Policy Research Working Paper No. 3556. April. World Bank. Washington DC, United States of America. Available at:

http://www.ifc.org/ifcext/rbcgp.nsf/AttachmentsByTitle/CreditRiskBasel2.pdf/\$FILE/CreditRiskBasel2.pdf [accessed 2007-07-26].

OESTERREICHISCHE NATIONALBANK. 2007. Basel II history. July. Vienna, Austria. Available at: http://www.oenb.at/en/finanzm_stab/basel_II/basisinfo/entstehungsgeschichte/basel_ii_history.jsp [accessed 2007-07-31].

OLSON RESEARCH. 2000. A/L Benchmarks industry report: standard for asset/liability management. $4^{\text {th }}$ Quarter. Columbia, United States of America. Available at: http:/www.olsonresearch.com/IndustryRpt/ PDF/2000Q4-IndustryReport.pdf [accessed 2007-10-22].

OR see OLSON RESEARCH.

RESERVE BANK OF AUSTRALIA. 1998. Liquidity risk management: prudential statement 1. April. Sydney, Australia. Available at: http://www.rba.gov.au/MediaReleases/1998/prudential_statement_d1 [accessed 2007-2-12].

SA see SOUTH AFRICA.

SAAYMAN, A. 2003. Securitisation and bank liquidity in South Africa. Paper presented at the Biannual Conference of the Economic Society of South Africa (ESSA) on Africa's Millenium: Trade, Investment and Growth. 17-19 September. Somerset West, South Africa. Available at: http://www.essa.org.za/download/ 2003Conference/SaaymanA_Securitisation\%20And\%20Bank\%20Liquidity\%20In\%20South\%20Africa.pdf [accessed 2007-02-13].

SARB see SOUTH AFRICAN RESERVE BANK. 


\section{SFRC see SHADOW FINANCIAL REGULATORY COMMITTEES.}

SHADOW FINANCIAL REGULATORY COMMITTEES. 1999. Improving the Basle committee's new capital adequacy framework. Joint statement by the shadow financial regulatory Committees of Europe, Japan and the US. 14 June. New York, United States of America. Available at: http://www.econ.keio.ac.jp/ staff/masaya//shadow/article/jointstate_1.doc [accessed 2007-07-14].

SHARMA, P. 2004. Speech on liquidity risk. 8 October. Financial Services Authority. London. England. Available at: http://www.fsa.gov.uk/Pages/Library/Communication/Speeches/2004/SP201.shtml [accessed 2007-01-27].

SOUTH AFRICA. 2000. Regulations relating to banks. (Proclamation No. R 1112, 2000) Government Gazette, 6917, 8 November. (Regulation Gazette No. 21726).

SOUTH AFRICAN RESERVE BANK. 2007a. Electronic DI Returns and other information available to the public: DI 100, DI 300, DI 310, DI 400, DI 900. June. Available at: http://www.resbank.co.za/sarbdata/ifdata/ default.asp [accessed 2007-06-10].

SOUTH AFRICAN RESERVE BANK. 2007b. List of eligible collateral. 23 May. Financial Markets Department. Pretoria, South Africa. Available at: http://www.reservebank.co.za/internet/Publication.nsf/ LADV/631936992C6C037F422572DB00494266/\$File/Eligible+Collateral+23+May+2007.pdf [accessed 2007-09-11].

STYGER, P. \& VOSLOO, P.G. 2005. The banker's guide to the Basel II Framework. December. Johannesburg, South Africa. Available at: http://www.banking.org.za/documents/2005/DECEMBER/ InfoDoc_29781.pdf [accessed 2007-03-19].

VAN ROY, P. 2005. Credit-ratings and the standardised approach to credit risk in Basel II. European Central Bank Working Paper Series No. 517. August. European Central Bank. Frankfurt, Germany. Available at: http://www.ecb.int/pub/pdf/scpwps/ecbwp517.pdf [accessed 2007-07-27].

WEINBERG, M. 2007. IIF report-principles of liquidity risk management: considerations for regulators. Presentation given at APRA Liquidity Risk Management Conference. 3-4 May. Available at: http://www.apra.gov.au/Policy/upload/2c-Mark-Weinberg-IIF-Report-Principles-of-liquidity-riskmanagement-Considerations-for-regulators.pdf [accessed 2007-06-7].

WEST, G. 2004. Risk measurement for financial institutions. Financial Modelling Agency, CAM Department, University of the Witwatersrand. 25 November. Johannesburg, South Africa. Available at: http://www.cam.wits.ac.za/mfinance/MPT2004/rm.pdf [accessed 2007-02-20].

WOLF, M. 2007. From a bank run to nationalising deposits, Article in Financial Times. 18 September. Available at: http://www.ft.com/cms/s/02658970-65ec-11dc-9fbb-0000779fd2ac,s01=1.html [accessed 2007-09-19]. 